\title{
Effect of Plant Growth Regulators and Chemical on Vegetative and Reproductive Parameters during Hasta Bahar in Acid Lime (Citrus aurantifolia Swingle)
}

\author{
Obadiya Rai ${ }^{*}$, S.N. Patil ${ }^{2}$, D.R. Patil ${ }^{1}$, Venkatshalu ${ }^{3}$, \\ Mallikarjun Awati ${ }^{4}$ and K.C. Kiran ${ }^{5}$
}

${ }^{1}$ Department of Fruit Science, College of Horticulture, Bagalkot, University of Horticultural Sciences, Bagalkot - 587104, Karnataka, India

${ }^{2}$ Department of Fruit Science, College of Horticulture, Arabhavi, University of Horticultural Sciences, Bagalkot - 587104, Karnataka, India

${ }^{3}$ Deparment of Entomology, College of Horticulture, University of Horticultural Sciences, Bagalkot - 587104, Karnataka, India

${ }^{4}$ Deparment of Crop Improvement and Biotechnology, College of Horticulture, University of Horticultural Sciences, Bagalkot - 587104, Karnataka, India

${ }^{5}$ Deparment of Plant Pathology, College of Horticulture, University of Horticultural Sciences, Bagalkot - 587104, Karnataka, India

*Corresponding author

\begin{tabular}{|c|c|}
\hline & A B S T R A C T \\
\hline Keywords & \multirow{4}{*}{$\begin{array}{l}\text { A field experiment was conducted to study the effect of plant growth regulators and } \\
\text { chemical on growth, flowering and yield of hasta bahar acid lime (Citrus aurantifolia } \\
\text { Swingle). The experiment was laid out in split plot design with two main plot treatments } \\
\text { and nine sub-plot treatments and three replications. The study revealed that, the application } \\
\text { of } \mathrm{GA}_{3} @ 50 \mathrm{ppm} \text { in June }+ \text { Cycocel @ } 1000 \mathrm{ppm} \text { in September }+\mathrm{KNO}_{3} @ 2 \% \text { in } \\
\text { October showed superior performance in regard to number of flowers per shoot (8.18), } \\
\text { number of fruits per tree }(382.50) \text {, initial fruit set }(54.74) \text { and fruit retention (39.73), yield } \\
\text { (4.13) and percentage increase in yield over control (52.43). } \mathrm{GA}_{3} @ 50 \mathrm{ppm} \text { in June } \\
\text { recorded highest increase in plant height, canopy spreads, canopy volume, shoot length } \\
\text { and also resulted in highest days taken to flowering. However, } \mathrm{KNO}_{3} @ 2 \% \text { in October } \\
\text { induced earliest flowering in acid lime. }\end{array}$} \\
\hline & \\
\hline Article Info & \\
\hline $\begin{array}{l}\text { Accepted: } \\
\text { 18 August } 2018 \\
\text { Available Online: } \\
\text { 10 September } 2018\end{array}$ & \\
\hline
\end{tabular}

\section{Introduction}

Acid lime (Citrus aurantifolia Swingle) is third most important fruit crop next to mandarin and sweet orange. It belongs to the genus Citrus, family Rutaceae and has chromosome number $(2 n=18)$. India is the largest producer of acid lime in the world with production of 2.84 million tonnes with productivity of $9.90 \mathrm{MT} / \mathrm{ha}$ (Anon, 2017). It is largely cultivated in Andhra Pradesh, Telangana, Karnataka, Odisha, Madhya Pradesh and Maharashtra, Assam, Bihar, Chattisgarh, Manipur, Jharkhand, Tamil Nadu, 
Tripura and Mizoram. It contains 6.3-6.6\% citric acid. It acts as an appetizer, stomachic, antiscorbutic, antihelmintic and checks biliousness besides a good source of nutrients, vitamins and other antioxidant compounds (Chadha, 2002).

Acid lime is considered to be continuous bloomer due to its peculiar cyclic flushing behaviour but the main blooming period starts from February to March with lean period from July to August. The flowering percentage of ambe, mrig and hasta bahar occurs $47 \%, 36 \%$ and $17 \%$ respectively (Pawar et al., 2016). The fruits of hasta bahar are ready to harvest in the months of April - May when there is heavy demand and are sold at premium prices. It is reported that acid lime market prices and arrivals have exactly inverse relationship in Vijaypur district market i.e. when arrivals were more in market, the prices started to decreased and vice versa (Thejeswini and Teggi, 2015). The scope of producing acid lime during summer months is significant and results in high returns to the growers. However, the major constraint is the plants bear not as much of flowering and fruiting in the uncontrolled condition because of the south west monsoon rains preceding the flower initiation during hasta bahar in South Indian conditions. Subsequently, there are several cultural methods to impose stress to the plant which will lead to flowering but found to have uncertain results under different conditions. Thus, the exogenous plant growth regulators and chemical was expected to have a deliberate influence on promoting vigorous vegetative growth postponing the reproductive phase and encourage better bud burst, increased flower production and ultimately yield of acid lime.

The present study therefore, was undertaken to investigate the effect of plant growth regulators and chemicals viz. gibberellic acid, cycocel, and potassium nitrate on vegetative and reproductive parameters of acid lime. Gibberellic acid was used for vegetative growth, cycocel as growth retardants to counter act gibberellins activities followed by potassium nitrate as a dormancy breaking agent for better bud bursting.

\section{Materials and Methods}

The present investigation was conducted at Horticulture Research Station, Tidagundi in Vijayapur district during 2017-2018. The station is geographically situated at an altitude of $629 \mathrm{~m}$ from mean sea level and latitude $16.97^{\circ} \mathrm{N}$ and longitude $75.75^{\circ} \mathrm{E}$. It comes under Northern dry zone of Karnataka. The experiment was laid out in split plot design with two main factors and nine sub factors and three replications. The plants were five years old and spaced in $6 \times 6$ metres. Table 6 shows the experimental detail of the carried out investigation.

The plant growth regulators and chemical, as per treatments were applied as a foliar spray with the aid of knapsack sprayer. Spray was carefully taken to avoid drifting effect of spray of one solution over the other treatment. The spraying was carried out during calm and sunny day in the morning time. The sprayer was washed thoroughly with running water after the application of every plant growth regulator solution spray. For general maintenance of orchard, the recommended doses of fertilizers were applied and irrigation was schedule once in 7-10 days interval.

Sanitation and plant protection measures/practices have been followed commonly in all the treatment. Observation was recorded at monthly intervals after the imposition of treatment for each replication and treatments. The data collected were subjected to Fisher ' $F$ ' test. The degree of probability employed in deciding the critical difference was 5 percent $(\mathrm{P}=0.05)$. 


\section{Results and Discussions}

The experimental results obtained from the present investigation are discussed and presented below in the following sub headings as:

\section{Effect of plant growth regulators and chemical on vegetative growth parameters}

\section{Plant height (m)}

The data obtained regarding plant height indicated that the plant height was significantly influenced by different treatment combination as shown in Table 1. The maximum plant height was recorded in $\mathbf{M}_{2}$ $(3.59 \mathrm{~m})$, which was followed by $\mathrm{M}_{1}(3.33 \mathrm{~m})$ and was on par with each other.

Regarding the sub plot, the maximum plant height was obtained in $\mathrm{S}_{1}(3.66 \mathrm{~m})$ with $\mathrm{GA}_{3}$ @ $50 \mathrm{ppm}$ during June which was on par with $\mathrm{S}_{4}, \quad \mathrm{~S}_{3}$, and $\mathrm{S}_{8}(3.58,3.54$ and $3.53 \mathrm{~m}$ respectively) and significantly superior over rest of the treatments. Concerning to the interactions, the maximum plant height was recorded in $\mathrm{M}_{2} \mathrm{~S}_{4}(3.93 \mathrm{~m})$ and the minimum was recorded in $\mathrm{M}_{2} \mathrm{~S}_{5}(3.13 \mathrm{~m})$. However, the growth rate and increase in plant height were found maximum in treatment consisting of $\mathrm{GA}_{3} @ 50$ ppm during June (i.e. $\mathrm{S}_{6}, \mathrm{~S}_{1}, \mathrm{~S}_{7}$ and $\mathrm{S}_{8}$ ) when compared to the other treatments. This might be due to the fact that gibberellins $\left(\mathrm{GA}_{3}\right)$ act as a growth promoter which stimulates rapid cell elongation due in part to the activation of intercalary meristematic region of the growing shoots and also increases the internodal length of the branches. In contrast, cycocel is a growth retardant which inhibits the plant growth by inhibiting the cyclization of geranylgeranyl pyrophosphate to copyallyl pyrophosphate in the gibberellins biosynthesis pathway. This inhibition results in the decrease cell division and elongation arresting the vegetative growth of the plant. Similar finding with respect to increase in vegetative shoot and plant height by the application of gibberellins $\left(\mathrm{GA}_{3}\right)$ and arrested vegetative growth with cycocel were obtained by other several authors viz. Babu and Lavania (1985), Jadhav (2000), Tahir et al., (2002), Shinde et al., (2008) and Debaje et al., (2010) respectively.

\section{Canopy spread (m) - North-south}

The different application of plant growth regulators and chemical at different concentrations had found to be profound influence on canopy spread of the acid lime as shown in Table 1. The data showed maximum north to south spread in $\mathrm{M}_{2}$ i.e. Sai Sharbati $(4.27 \mathrm{~m})$ followed by $\mathrm{M}_{1}$ i.e. Phule Sharbati $(4.14 \mathrm{~m})$. Maximum canopy spread was recorded in $\mathrm{S}_{4}(4.42 \mathrm{~m})$ i.e. cycocel @ 1500 ppm in September and the minimum plant spread was recorded in $S_{7}(4.00 \mathrm{~m})$. However, it is noteworthy that the maximum increase in north to south spread was noticed in $\mathrm{S}_{6}, \mathrm{~S}_{7}, \mathrm{~S}_{8}$ and $S_{1}$ which was treated with $\mathrm{GA}_{3}(50 \mathrm{ppm})$ during June. As regard to interactions, the maximum north to south spread was recorded in $\mathrm{M}_{2} \mathrm{~S}_{2}(4.56 \mathrm{~m})$.

The role of $\mathrm{GA}_{3}$ in enhancing the mean north to south spread by promoting cell division and their elongation might have resulted in increased length of the branches. These findings were similar with Babu and Lavania (1985) in lemon, Nath and Baruah (1997) in Assam lemon, Jadhav (2000) in Jambhiri and Rangapur lime.

\section{Canopy spread (m) - East-west}

There was no significant difference found between main plot treatments as showed in Table 1. With respect to subplot, the maximum canopy spread was recorded in $S_{1}$ $(4.72 \mathrm{~m})$ with $\mathrm{GA}_{3} @ 50$ ppm during June which was on par with $S_{8}(4.71 \mathrm{~m})$ and $S_{6}$ 
$(4.58 \mathrm{~m})$. As concerned to the interactions, $\mathrm{M}_{2} \mathrm{~S}_{1}(4.93 \mathrm{~m})$ recorded the maximum eastwest canopy spread. This huge increase in east-west spread may be attributed to the promoting effect of $\mathrm{GA}_{3}$ in vegetative growth of the acid lime thus increasing the mean east to west spread. These findings were in conformity with Babu and Lavania (1985) in lemon, Nath and Baruah (1997) in Assam lemon, Jadhav (2000) in Jambhiri and Rangapur lime.

\section{Canopy volume $\left(\mathrm{m}^{3}\right)$}

There were significant differences found with application of plant growth regulators and chemical at their different concentrations in main plot, sub plot and interactions as presented in Table 2. Treatment $\mathrm{M}_{2}$ (Sai Sharbati) was recorded with maximum canopy volume $\left(28.53 \mathrm{~m}^{3}\right)$ as compared to $\mathrm{M}_{1}(24.19$ $\mathrm{m}^{3}$ ) i.e. Phule Sharbati.

In subplots, $\mathrm{S}_{1}\left(\mathrm{GA}_{3} @ 50\right.$ ppm during June $)$ recorded the maximum canopy volume (31.59 $\left.\mathrm{m}^{3}\right)$ and the minimum was in $\mathrm{S}_{7}\left(21.31 \mathrm{~m}^{3}\right)$. However, there is noticeable increase in the plant canopy volume in case of $\mathrm{S}_{6}, \mathrm{~S}_{1}, \mathrm{~S}_{8}$ and $\mathrm{S}_{7}$ than the other treatments. In interaction, the maximum canopy volume was recorded in $\mathrm{M}_{2} \mathrm{~S}_{1}\left(34.85 \mathrm{~m}^{3}\right)$. These increases in canopy volume might be due to the effect of gibberellins in internodal length, leaf expansion and length of branches which resulted increase in plant height and spread thus ultimately increasing the canopy volume. The findings are in similarity with Shah and Samiullah (2006), Debaje et al., (2010), Jagtap et al., (2013), Deshmukh et al., (2015) and Pawar et al., (2016) respectively.

\section{Length of shoot at flowering (cm)}

The data recorded on length of shoot at flowering (Table 2) indicated statistically significant differences among the main plot where $\mathrm{M}_{2}(13.00 \mathrm{~cm})$ showed the maximum shoot length and the minimum was recorded in $\mathrm{M}_{1}(12.67 \mathrm{~cm})$. The maximum shoot length $(17.89 \mathrm{~cm})$ was recorded in $\mathrm{S}_{1}\left(\mathrm{GA}_{3} @ 50\right.$ ppm during June) while the minimum shoot length was recorded in $\mathrm{S}_{8}(10.12 \mathrm{~cm})$.

As regard to interactions, the maximum length of shoot at flowering was recorded in $\mathrm{M}_{2} \mathrm{~S}_{1}$ $(19.36 \mathrm{~cm})$ and the minimum was observed in $\mathrm{M}_{2} \mathrm{~S}_{8}(10.05 \mathrm{~m})$ and found significantly different.

This maximum shoot length in $S_{1}$ may be due to the fact that the $\mathrm{GA}_{3}$ increased the osmotic uptake of nutrients from the soil, causing cells to elongate resulting in increased shoot length. It may be also due to the stimulatory effect of $\mathrm{GA}_{3}$ on extension and elongation of shoot, reducing generative shoots and increasing vegetative shoots in the plant (Guha and Chaturvedi, 1972).

Similar results have been found by Singh et al., 2017, Debaje et al., 2010 in acid lime and Shinde et al., 2008.

Effect of plant growth regulators and chemical on reproductive parameters

\section{Number of flowers per shoot}

The application of different concentration of growth regulators and chemicals had significantly influenced the number of flowers per shoot. There was non-significant difference found within the main plot.

The application of $\mathrm{GA}_{3} @ 50$ ppm in June + Cycocel@1000 ppm in Sept + KNO 3 @2\% in October $\left(\mathrm{S}_{6}\right)$ resulted in maximum number of flowers per shoot (8.18) and found significantly superior over the control (5.15). As regard to interactions, the maximum number of flowers was recorded in $\mathrm{M}_{2} \mathrm{~S}_{6}$ (8.26) and $\mathrm{M}_{1} \mathrm{~S}_{6}(8.10)$ respectively. 
Table.1 Effect of plant growth regulators and chemical on plant height and canopy spreads of acid lime

\begin{tabular}{|c|c|c|c|c|c|c|c|c|c|}
\hline \multirow[t]{2}{*}{ Treatments } & \multicolumn{3}{|c|}{ Plant height (m) } & \multicolumn{3}{|c|}{ Canopy spread N-S (m) } & \multicolumn{3}{|c|}{ Canopy spread E-W (m) } \\
\hline & $\mathbf{M}_{1}$ & $\mathbf{M}_{2}$ & Mean & $\mathbf{M}_{1}$ & $\mathbf{M}_{2}$ & Mean & $\mathbf{M}_{1}$ & $\mathbf{M}_{2}$ & Mean \\
\hline$S_{1}$ & $3.48(2.91)$ & $3.85(2.70)$ & 3.66 & $4.46(3.85)$ & $4.36(3.95)$ & 4.41 & $4.51(3.83)$ & $4.93(4.30)$ & 4.72 \\
\hline $\mathbf{S}_{2}$ & $3.33(3.30)$ & $3.63(3.63)$ & 3.48 & $3.76(3.76)$ & $4.56(4.56)$ & 4.17 & $3.96(3.96)$ & $4.53(4.53)$ & 4.25 \\
\hline $\mathbf{S}_{3}$ & $3.35(3.28)$ & $3.73(3.73)$ & 3.54 & $3.73(3.73)$ & $4.36(4.36)$ & 4.05 & $4.10(4.10)$ & $4.33(4.33)$ & 4.21 \\
\hline $\mathbf{S}_{4}$ & $3.23(3.23)$ & $3.93(3.93)$ & 3.58 & $4.36(4.36)$ & $4.46(4.46)$ & 4.42 & $4.40(4.40)$ & $4.66(4.66)$ & 4.53 \\
\hline $\mathbf{S}_{5}$ & $3.38(3.38)$ & $3.13(3.13)$ & 3.25 & $4.30(4.30)$ & $3.90(3.90)$ & 4.10 & $4.43(4.43)$ & $3.76(3.76)$ & 4.10 \\
\hline $\mathrm{S}_{6}$ & $3.36(2.46)$ & $3.53(2.70)$ & 3.45 & $4.33(3.40)$ & $4.36(3.40)$ & 4.35 & $4.43(3.08)$ & $4.73(3.58)$ & 4.58 \\
\hline $\mathrm{S}_{7}$ & $3.20(2.56)$ & $3.36(2.58)$ & 3.28 & $4.10(3.20)$ & $3.90(3.23)$ & 4.00 & $4.13(3.20)$ & $3.96(3.33)$ & 4.05 \\
\hline $\mathbf{S}_{8}$ & $3.26(2.60)$ & $3.80(3.03)$ & 3.53 & $4.03(3.30)$ & $4.30(3.53)$ & 4.17 & $4.90(3.50)$ & $4.53(3.86)$ & 4.71 \\
\hline $\mathrm{S}_{9}$ & $3.41(3.28)$ & $3.33(3.25)$ & 3.37 & $4.20(4.13)$ & $4.23(4.13)$ & 4.22 & $4.23(4.23)$ & $4.23(4.13)$ & 4.23 \\
\hline \multirow[t]{2}{*}{ Mean } & 3.33 & 3.59 & & 4.14 & 4.27 & & 4.34 & 4.41 & \\
\hline & S.Em \pm & \multicolumn{2}{|c|}{ C.D. @ $5 \%$} & S.Em \pm & \multicolumn{2}{|c|}{ C.D. @ $5 \%$} & \multicolumn{3}{|c|}{ C.D. @ $5 \%$} \\
\hline $\mathbf{M}$ & 0.09 & \multicolumn{2}{|c|}{0.42} & 0.07 & \multicolumn{2}{|c|}{0.11} & 1.36 & \multicolumn{2}{|c|}{0.23} \\
\hline $\mathbf{S}$ & 0.11 & \multicolumn{2}{|c|}{0.34} & 0.11 & \multicolumn{2}{|c|}{0.45} & 2.23 & \multicolumn{2}{|c|}{0.47} \\
\hline $\mathbf{M} \times \mathbf{S}$ & 0.17 & \multicolumn{2}{|c|}{0.48} & 0.17 & \multicolumn{2}{|c|}{0.64} & 3.27 & \multicolumn{2}{|c|}{0.67} \\
\hline
\end{tabular}

Table.2 Effect of plant growth regulators and chemical on canopy volume and length of shoots of acid lime

\begin{tabular}{|c|c|c|c|c|c|c|}
\hline \multirow[t]{2}{*}{ Treatments } & \multicolumn{3}{|c|}{ Canopy volume $\left(\mathrm{m}^{3}\right)$} & \multicolumn{3}{|c|}{ Length of shoot at flowering (cm) } \\
\hline & $\mathbf{M}_{1}$ & $\mathbf{M}_{2}$ & Mean & $\mathbf{M}_{1}$ & $\mathbf{M}_{2}$ & Mean \\
\hline$S_{1}$ & $28.33(16.08)$ & $34.85(16 . \mathrm{s} 96)$ & 31.59 & 16.43 & 19.36 & 17.89 \\
\hline $\mathrm{S}_{2}$ & $20.12(20.12)$ & $31.50(31.50)$ & 25.81 & 16.33 & 16.79 & 16.56 \\
\hline $\mathrm{S}_{3}$ & $20.79(20.79)$ & $29.76(29.62)$ & 25.27 & 12.21 & 12.41 & 12.31 \\
\hline $\mathbf{S}_{4}$ & $24.91(24.91)$ & $34.64(34.64)$ & 29.77 & 12.15 & 12.03 & 12.09 \\
\hline $\mathbf{S}_{5}$ & $25.77(25.77)$ & $18.38(18.38)$ & 22.07 & 11.98 & 11.90 & 11.94 \\
\hline$S_{6}$ & $26.03(9.39)$ & $29.86(12.59)$ & 27.95 & 10.58 & 10.30 & 10.44 \\
\hline $\mathrm{S}_{7}$ & $21.62(9.66)$ & $21.00(10.25)$ & 21.31 & 10.41 & 10.25 & 10.33 \\
\hline $\mathrm{S}_{8}$ & $25.76(10.90)$ & $30.66(16.09)$ & 28.21 & 10.20 & 10.05 & 10.12 \\
\hline $\mathrm{S}_{9}$ & $24.35(22.77)$ & $26.15(21.90)$ & 25.25 & 13.74 & 13.95 & 13.84 \\
\hline \multirow[t]{2}{*}{ Mean } & 24.19 & 28.53 & - & 12.67 & 13.00 & - \\
\hline & S.Em \pm & \multicolumn{2}{|c|}{ C.D. @ $5 \%$} & \multicolumn{2}{|c|}{ S.Em \pm} & C.D. @ $5 \%$ \\
\hline $\mathbf{M}$ & 1.28 & \multicolumn{2}{|c|}{7.76} & \multicolumn{2}{|c|}{0.28} & 1.76 \\
\hline $\mathbf{S}$ & 2.52 & \multicolumn{2}{|c|}{7.25} & \multicolumn{2}{|c|}{0.42} & 1.22 \\
\hline $\mathbf{M} \times \mathbf{S}$ & 3.60 & \multicolumn{2}{|c|}{10.26} & \multicolumn{2}{|c|}{0.64} & 1.73 \\
\hline
\end{tabular}

*Values in parenthesis shows reading before treatment 
Table.3 Effect of plant growth regulators and chemical on no. of flowers per shoot, days taken to flowering and no. of fruits per tree of acid lime

\begin{tabular}{|c|c|c|c|c|c|c|c|c|c|}
\hline \multirow[t]{2}{*}{ Treatments } & \multicolumn{3}{|c|}{ Number flowers per shoot } & \multicolumn{3}{|c|}{ Number of days taken to flowering } & \multicolumn{3}{|c|}{ Number of fruits per tree } \\
\hline & $\mathbf{M}_{1}$ & $\mathbf{M}_{2}$ & Mean & $\mathbf{M}_{1}$ & $\mathbf{M}_{2}$ & Mean & $\mathbf{M}_{1}$ & $\mathbf{M}_{2}$ & Mean \\
\hline$S_{1}$ & 4.74 & 4.31 & 4.53 & 153.00 & 153.33 & 153.16 & 216.67 & 213.33 & 215.00 \\
\hline $\mathbf{S}_{2}$ & 5.51 & 5.61 & 5.56 & 32.00 & 32.66 & 32.33 & 273.33 & 213.33 & 243.33 \\
\hline$S_{3}$ & 5.70 & 6.16 & 5.93 & 58.33 & 58.00 & 58.16 & 206.66 & 220.00 & 213.33 \\
\hline $\mathbf{S}_{4}$ & 6.26 & 6.31 & 6.29 & 55.33 & 54.66 & 55.00 & 218.19 & 280.00 & 249.09 \\
\hline$S_{5}$ & 6.03 & 5.96 & 6.00 & 53.66 & 54.00 & 53.83 & 266.66 & 233.33 & 250.00 \\
\hline$S_{6}$ & 8.10 & 8.26 & 8.18 & 150.00 & 150.66 & 150.33 & 385.00 & 380.00 & 382.50 \\
\hline $\mathrm{S}_{7}$ & 7.88 & 7.83 & 7.85 & 148.66 & 149.33 & 149.00 & 333.33 & 326.67 & 330.00 \\
\hline $\mathbf{S}_{8}$ & 7.44 & 7.80 & 7.62 & 146.66 & 147.33 & 147.00 & 278.33 & 290.00 & 284.16 \\
\hline $\mathrm{S}_{9}$ & 5.13 & 5.16 & 5.15 & 142.33 & 141.33 & 141.83 & 186.66 & 210.00 & 198.33 \\
\hline \multirow[t]{2}{*}{ Mean } & 6.31 & 6.38 & - & 104.44 & 104.59 & - & 262.72 & 262.96 & - \\
\hline & \multicolumn{2}{|c|}{ S.Em \pm} & C.D. @ $5 \%$ & \multicolumn{2}{|c|}{ S.Em \pm} & C.D. @ $5 \%$ & \multicolumn{2}{|c|}{ S.Em \pm} & C.D. @ $5 \%$ \\
\hline $\mathbf{M}$ & \multicolumn{2}{|c|}{0.04} & NS & \multicolumn{2}{|c|}{0.22} & NS & \multicolumn{2}{|c|}{5.58} & NS \\
\hline $\mathrm{S}$ & \multicolumn{2}{|c|}{0.12} & 0.34 & \multicolumn{2}{|c|}{0.94} & 2.71 & \multicolumn{2}{|c|}{30.92} & 89.07 \\
\hline $\mathbf{M} \times \mathbf{S}$ & \multicolumn{2}{|c|}{0.16} & 0.48 & \multicolumn{2}{|c|}{1.36} & NS & \multicolumn{2}{|c|}{41.60} & NS \\
\hline
\end{tabular}

Table.4 Effect of plant growth regulators and chemical on initial fruit set, frit retention and average fruit weight of acid lime

\begin{tabular}{|c|c|c|c|c|c|c|c|c|c|}
\hline \multirow[t]{2}{*}{ Treatments } & \multicolumn{3}{|c|}{ Initial fruit set $(\%)$} & \multicolumn{3}{|c|}{ Fruit retention at harvest (\%) } & \multicolumn{3}{|c|}{ Average fruit weight (g) } \\
\hline & $\mathbf{M}_{1}$ & $\mathbf{M}_{2}$ & $\mathbf{M}_{1}$ & $\mathbf{M}_{2}$ & Mean & Mean & $\mathbf{M}_{1}$ & $\mathbf{M}_{2}$ & Mean \\
\hline$S_{1}$ & 40.41 & 41.24 & 40.82 & 30.91 & 31.05 & 30.98 & 34.33 & 40.33 & 37.33 \\
\hline $\mathbf{S}_{2}$ & 42.47 & 44.77 & 43.62 & 28.70 & 29.50 & 29.10 & 32.16 & 39.00 & 35.58 \\
\hline $\mathbf{S}_{3}$ & 46.55 & 47.06 & 46.81 & 35.07 & 35.37 & 35.22 & 36.50 & 36.33 & 36.41 \\
\hline $\mathbf{S}_{4}$ & 46.02 & 46.09 & 46.05 & 33.05 & 33.18 & 33.11 & 36.83 & 31.50 & 34.16 \\
\hline $\mathbf{S}_{5}$ & 45.53 & 43.04 & 44.29 & 32.37 & 32.26 & 32.32 & 37.50 & 41.00 & 39.25 \\
\hline$S_{6}$ & 54.26 & 55.22 & 54.74 & 39.41 & 40.05 & 39.73 & 40.00 & 37.16 & 38.58 \\
\hline$S_{7}$ & 53.39 & 51.40 & 52.39 & 37.04 & 37.85 & 37.45 & 39.16 & 38.83 & 39.00 \\
\hline$S_{8}$ & 51.66 & 51.30 & 51.48 & 36.62 & 33.66 & 35.14 & 38.83 & 40.10 & 39.46 \\
\hline$S_{9}$ & 41.52 & 43.76 & 42.64 & 26.91 & 27.64 & 27.28 & 37.83 & 34.16 & 36.00 \\
\hline \multirow[t]{2}{*}{ Mean } & 46.87 & 47.10 & - & 33.34 & 33.40 & - & 37.01 & 37.60 & - \\
\hline & \multicolumn{2}{|c|}{ S.Em \pm} & C.D. @ 5\% & \multicolumn{2}{|c|}{ S.Em \pm} & C.D. @ 5\% & \multicolumn{2}{|c|}{ S.Em \pm} & C.D.@ $5 \%$ \\
\hline $\mathbf{M}$ & \multicolumn{2}{|c|}{0.34} & NS & \multicolumn{2}{|c|}{0.15} & NS & \multicolumn{2}{|c|}{0.40} & 2.40 \\
\hline $\mathbf{S}$ & \multicolumn{2}{|c|}{2.20} & 35 & \multicolumn{2}{|c|}{0.92} & 2.67 & \multicolumn{2}{|c|}{1.22} & 3.54 \\
\hline $\mathrm{M} \times \mathbf{S}$ & \multicolumn{2}{|c|}{2.96} & IS & \multicolumn{2}{|c|}{1.25} & NS & \multicolumn{2}{|c|}{1.68} & 4.99 \\
\hline
\end{tabular}


Table.5 Effect of plant growth regulators and chemical on yield parameters of acid lime

\begin{tabular}{|c|c|c|c|c|c|c|}
\hline \multirow[t]{2}{*}{ Treatments } & \multicolumn{3}{|c|}{ Yield (t/ha) } & \multicolumn{3}{|c|}{ Per cent increase in yield over control } \\
\hline & $\mathbf{M}_{1}$ & $\mathbf{M}_{2}$ & Mean & $\mathbf{M}_{1}$ & $\mathbf{M}_{2}$ & Mean \\
\hline $\mathbf{S}_{1}$ & 2.05 & 2.61 & 2.33 & 4.88 & 24.14 & 14.51 \\
\hline $\mathbf{S}_{2}$ & 2.44 & 2.27 & 2.36 & 20.08 & 12.78 & 16.43 \\
\hline $\mathbf{S}_{3}$ & 2.10 & 2.23 & 2.16 & 7.14 & 11.21 & 9.18 \\
\hline $\mathbf{S}_{4}$ & 2.23 & 2.50 & 2.36 & 12.56 & 20.80 & 16.68 \\
\hline $\mathbf{S}_{5}$ & 2.75 & 2.65 & 2.70 & 29.09 & 25.28 & 27.19 \\
\hline $\mathbf{S}_{6}$ & 4.26 & 4.01 & 4.13 & 54.23 & 50.62 & 52.43 \\
\hline $\mathbf{S}_{7}$ & 3.59 & 3.51 & 3.55 & 45.68 & 43.59 & 44.64 \\
\hline $\mathbf{S}_{8}$ & 3.00 & 3.23 & 3.11 & 35.00 & 38.70 & 36.85 \\
\hline$\overline{\mathbf{S}_{9}}$ & 1.95 & 1.98 & 1.97 & 0.00 & 0.00 & 0.00 \\
\hline \multirow[t]{2}{*}{ Mean } & 2.75 & 2.77 & - & 23.18 & 25.24 & - \\
\hline & S.Em \pm & \multicolumn{2}{|c|}{ C.D. @ $5 \%$} & \multicolumn{2}{|c|}{ S.Em \pm} & C.D. @ $5 \%$ \\
\hline$\overline{\mathbf{M}}$ & 0.06 & \multicolumn{2}{|c|}{0.37} & \multicolumn{2}{|c|}{5.03} & NS \\
\hline $\mathbf{S}$ & 0.34 & \multicolumn{2}{|c|}{0.98} & \multicolumn{2}{|c|}{9.76} & 28.24 \\
\hline $\mathbf{M} \times \mathbf{S}$ & 0.45 & \multicolumn{2}{|c|}{1.38} & \multicolumn{2}{|c|}{13.95} & NS \\
\hline \multicolumn{4}{|c|}{$\begin{array}{l}\text { Sub plot treatments: } \\
\mathbf{S}_{\mathbf{1}}-\mathrm{GA}_{3} @ 50 \mathrm{ppm} \text { in June } \\
\mathrm{S}_{2}-\mathrm{KNO}_{3} @ 2 \% \text { in October } \\
\mathbf{S}_{\mathbf{3}}-\mathrm{Cycocel} @ 1000 \mathrm{ppm} \text { in September } \\
\mathbf{S}_{\mathbf{4}}-\mathrm{Cycocel} @ 1500 \mathrm{ppm} \text { in September } \\
\mathbf{S}_{5}-\mathrm{Cycocel} @ 2000 \mathrm{ppm} \text { in September } \\
\mathbf{S}_{\mathbf{6}}-\mathrm{GA}_{3} @ 50 \mathrm{ppm} \text { in June }+ \text { Cycocel @ } 1000 \mathrm{ppm} \text { in Sept }+\mathrm{KNO}_{3} @ 2 \% \text { in October } \\
\mathbf{S}_{7}-\mathrm{GA}_{3} @ 50 \mathrm{ppm} \text { in June }+ \text { Cycocel @ } 1500 \mathrm{ppm} \text { in Sept }+\mathrm{KNO}_{3} @ 2 \% \text { in October } \\
\mathbf{S}_{\mathbf{8}}-\mathrm{GA}_{3} @ 50 \mathrm{ppm} \text { in June }+ \text { Cycocel @ } 2000 \mathrm{ppm} \text { in Sept }+\mathrm{KNO}_{3} @ 2 \% \text { in October } \\
\mathbf{S}_{\mathbf{9}}-\mathrm{Control}\end{array}$} & \multicolumn{3}{|c|}{$\begin{array}{l}\text { Main plot treatme } \\
\mathrm{M}_{1} \text { - Phule Sharbati } \\
\mathrm{M}_{2} \text { - Sai Sharbati }\end{array}$} \\
\hline
\end{tabular}




\section{Table.6 Experimental details}

Main plot treatments:

$\mathbf{M}_{1}$ - Phule Sharbati

$\mathbf{M}_{2}$ - Sai Sharbati

Sub-plot treatments:

$\mathrm{S}_{1^{-}}$GA 3 @ 50 ppm in June

$\mathrm{S}_{2-} \mathrm{KNO}_{3} @ 2 \%$ in October

$\mathrm{S}_{3}$ - Cycocel @ 1000 ppm in September

$\mathrm{S}_{4}$ - Cycocel @ 1500 ppm in September

$\mathrm{S}_{5^{-}}$Cycocel @ 2000 ppm in September

$\mathrm{S}_{6-} \mathbf{G A}_{3} @ 50$ ppm in June + Cycocel @ 1000 ppm in Sept + $\mathrm{KNO}_{3} @ 2$ \% in October

$\mathrm{S}_{7}-\mathrm{GA}_{3} @ 50$ ppm in June + Cycocel @ 1500 ppm in Sept + $\mathrm{KNO}_{3} @ 2 \%$ in October

$\mathrm{S}_{8^{-}} \mathbf{G A}_{3} @ 50$ ppm in June + Cycocel @ 2000 ppm in Sept + $\mathrm{KNO}_{3} @ 2$ \% in October

$\mathbf{S}_{9^{-}}$Control (No spray)

This may be due to the action of growth retardant (cycocel) which was sprayed during September month, might have acted as antigibberellins by blocking the gibberellins synthesis and arrested the vegetative growth, nucleic acid synthesis and protein metabolism which ultimately induced reproductive bud formation. Similar results have been reported by Thirugnanavel et al., (2007), Deshmukh et al., (2014), Mohsen Kazemi (2014), Debbarma and Hazarika (2016), Pawar et al., (2016).

\section{Number of days taken to flowering}

The application of different concentration of growth regulators and chemical had influenced significant difference on number of days taken to flowering in sub plot. However, there was no significant difference found with regard to main plot and interactions. With respect to sub plot, the minimum days to flowering was observed in $\mathrm{S}_{2}$ (32.33) i.e. $\mathrm{KNO}_{3} @ 2 \%$ and the maximum in $\mathrm{S}_{1}(153.16)$ i.e. $\left(\mathrm{GA}_{3} @ 50 \mathrm{ppm}\right.$ in June) which was on par with $S_{6}(150.33)$. The lateness in flowering with the $\mathrm{GA}_{3}$ treatment might be due to its effect on the promotion and diversion of metabolites and flower inducing substances which changes the fate of reproductive buds to vegetative buds and inhibition of flower development. Guardiola et al., (1977) concluded that the main effect of $\mathrm{GA}_{3}$ lies in the inhibition of bud development. Similar findings in regard to days to flowering was reported by Ghora $e t$ al., (2000), Azam et al., (2007), Deshmukh et al., (2014), Debbarma and Hazarika (2016) respectively.

\section{Average fruit weight (g)}

There were no significant differences between the main plot treatments. The maximum average fruit weight (39.46) was observed in $\mathrm{S}_{8}$ i.e. $\mathrm{GA}_{3} @ 50 \mathrm{ppm}$ in June + Cycocel @ 2000 ppm in Sept + $\mathrm{KNO}_{3} @ 2 \%$ in October and was on par with $\mathrm{S}_{5}(39.25), \mathrm{S}_{7}$ (39.00) and $S_{6}$ (38.58), $S_{1}$ (37.33) and $S_{3}$ (36.41) respectively. As concerned to interactions, the maximum average fruit weight (41.00) was seen in $\mathrm{M}_{2} \mathrm{~S}_{5}$ i.e. Cycocel @ $2000 \mathrm{ppm}$ in September and was on par with $\mathrm{M}_{2} \mathrm{~S}_{1}$ (40.33), $\mathrm{M}_{2} \mathrm{~S}_{8}$ (40.10) and $\mathrm{M}_{1} \mathrm{~S}_{6}$ (40.00) respectively. This increase in fruit weight might be due to the transient increase in cell number and cell division or combination of both in cells of ovary caused by gibberellins. As gibberellins have synergistic effect on auxin production resulted in cell enlargement resulting in 
increased vesicle size and potassium might have regulated more assimilates diversion into the developing fruits.

The results were in conformity with Mukunda et al., (2014), Pawar et al., (2016), Pawar et al., (2016a). Similar results regarding increase in average fruit weight by gibberellins were reported by Chandra et al., (2015), Rokaya et al., (2016), Meena et al., (2017). Similar results regarding fruit weight by cycocel and potassium nitrate were reported by Mahalle et al., (2010) and Somavanshi et al., (2012) respectively.

\section{Yield (t/ha)}

The data presented regarding yield per tree and in the previous chapter showed the nonsignificant differences in main plot and interactions.

The maximum yield per hectare (4.31) was recorded in $\mathrm{S}_{6}\left(\mathrm{GA}_{3} @ 50 \mathrm{ppm}\right.$ in June + Cycocel @ 1000 ppm in September $+\mathrm{KNO}_{3}$ @ $2 \%$ in October) and was on par with $\mathrm{S}_{7}$ (4.01).

The minimum yield per hectare was recorded in control i.e. $\mathrm{S}_{9}$ (1.97). This increased yield may be attributed to the more photosynthetic area with more vegetative growth attained due to the application of gibberellins in June, and cycocel applied during September might have enacted in converting the carbohydrate assimilates into flower bud initiation and fruit development process.

Later, the application of potassium nitrate during October might help in more bud bursting and more fruit setting. The results were in conformity with the findings of Thirugnanavel et al., (2007), Mukunda et al., (2014) and Ranganna et al., (2017) i.e. $\mathrm{GA}_{3}$ @ 50 ppm in June + Cycocel @ 1000 ppm in September $+\mathrm{KNO}_{3} @ 2 \%$ in October.

\section{Per cent increase in yield over control}

The data presented in the previous chapter clearly shows that the application of different concentration of growth regulators and chemicals had significantly influenced percent increase in yield over control. There were statistically non-significant differences found in main plot treatments and interaction.

The maximum percent increase in yield over control (52.43) was seen in $\mathrm{S}_{6}\left(\mathrm{GA}_{3} @ 50\right.$ ppm in June + Cycocel @ 1000 ppm in September $+\mathrm{KNO}_{3} @ 2 \%$ in October) and was on par with $S_{7}$ (44.64), $S_{8}(36.85)$ and $S_{5}$ (27.19). The similar kinds of results were reported by Yeshitela (2004) in mango cv. Tommy Atkins and Nahar et al., (2010) in mango cv. Amrapali.

Gibberelic acid was found to be best option to extend flowering period in acid lime during hasta bahar and also to promote more vegetative growth. Similarly, cycocel acted to inhibit the growth attained by gibberellins and encourage flower bud formation assisted by the action of potassium nitrate as bud dormancy breaking agent.

\section{Acknowledgement}

The authors are thankful to Professor and Head, Department of Fruit Science, College of Horticulture, Bagalkot, Dean, College of Horticulture, Bagalkot as well as the Director of Research and Dean Post Graduate Studies, University of Horticultural Sciences, Bagalkot for providing all the necessary facilities during the course of the study.

\section{References}

Anonymous, 2017, Horticulture Statistics at a Glance, pp. 141-142.

Azam, M., Tabir, F. M., Anwar, R., Pervez, M. A. and Shoaib-ur-Rehman, 2007, 
Effect of gibberellic acid and potassium nitrate spray on panicle physiology of mango (Mangifera indica L). Inst. Hort. Sci., University of Agriculture, Faridabad.

Babu, G. H. V. R. and Lavania, M. L., 1985, Effect of plant growth regulators on fruit set and fruit drop of Pant Lemon-1. Indian J. Hort., 42: 237-240.

Chadha, K. L., Handbook of Horticulture, ICAR publication, New Delhi, 2002, pp: 209.

Chandra, R., Manju, Rawat, S. S. and Singh, K. K., 2015, Effect of foliar application of various plant growth regulators on yield and quality of Aonla (Phyllanthus emblica Gaerth L.) cv. NA-7. Int. J. Trop. Agri., 33: 2123-2127.

Debaje, P., Shinde, P., Ekta, D. and Ingale, H. V., 2011, Effect of plant growth regulators and nutrients on quality of Acid lime (Citrus aurantifolia Swingle). Asian J. Horti., 6 253-255.

Debbarma, N. and Hazarika, B.N., 2016, Effect of plant growth regulators and chemicals on yield and quality of acid lime (Citrus aurantifolia Swingle) under foothill condition of Arunachal Pradesh. Int. J. Agri. Env. Biotechn., 9: 231-236.

Deshmukh, U. B., Chate, V. M. and Bawkar, S.O., 2014, Effect of plant growth substances on growth, flowering and fruit set in acid lime. Bioinfolet, 11: 6466.

Ghora, Y., Vasilakakis, M. and Stavroulakis, G., 2000, Effect of growth retardants (CCC, Daminozide \& Paclobutrazol) on growth and development of red raspberries cv. 'Autum Bliss' cultivated under plastic greenhouse condition in China- Crete, Greece. Acta Hort., 513: 453-458.

Guardiola, J. L., Augusti, M. and GarciaMari, F., 1977, Gibberellic acid and flower development in sweet orange, Proc. Int. Soc. Citriculture, 2: 696-699.

Guha, D. B. and Chaturvedi, K. N., 1972, Preliminary studies on the effect of gibberellic acid and CCC (2Chloroethyl trimethyl ammonium chloride) on vegetative growth, flowering and fruit set in transplanted seedlings of papaya. Punjab Horti. J., 12: 111-113.

Jadhav, S. B., 2000, Effect of growth regulators and urea sprays on growth of Jambheri and Rangpur lime rootstock seedlings. M.Sc (Agri.) Thesis, Dr. P. D. K. V., Akola.

Jagtap, V. M., Patel, H. C., Nehete, D. S. and Godage, S. S., 2013, Effect of foliar application of plant growth regulators and micronutrients on yield and quality of acid lime cv. Kagzi (Citrus aurantifolia Swingle). Asian J. Hort., 8: 57-59.

Mahalle, S. S., Ingle, H. V. and Sable, P. B. 2010, Influence of plant growth regulators and chemicals on yield and quality of hasta bahar in Acid lime, Green Farm, 1: 285-87.

Mohsen Kazemi, 2014, Effect of $\mathrm{GA}_{3}$ and $\mathrm{KNO}_{3}$ spray on vegetative growth and reproductive characteristics of tomato. Int. J. Biol. and Environ. Sci., 8: 1-9.

Nahar, N., Choudhary, M. S. H. and Rahim, M. A., 2010, Effect of $\mathrm{KClO}_{3}, \mathrm{KNO}_{3}$ and urea on the flowering and fruiting of mango and longan. J. Agro. Forestry \& Environ., 4: 31-34.

Nath, J. C. and Baruah, K., 1999, Regulation of plant growth, flowering time and yield in Assam lemon (Citrus limon Burn) with the help of pruning and growth regulators. Indian J. Agri. Sci., 69: 275-285.

Pawar, P. S., Bhise, P. B. and Dalal, N. R., 2016, Effect of plant growth regulators and chemicals on Acid lime (Citrus 
aurantifolia Swingle) cv. Phule Sharbati. Bioinfolet, 13: 606-609.

Pawar, P. S., Jagtap, D. D. and Patil, D. D., 2016, Effect of plant growth regulators and chemicals on yield of Acidlime (Citrus aurantifolia Swingle) during hasta bahar. Bioinfolet, 13: 176-178.

Shah, S. H. and Samiullah, 2006, Effect of phytohormones on growth and yield of Black cumin (Nigella sativa L.). Indian J. Plant Physiol., 11: 217-221.

Shinde, B. B., Ingle, H. V., Dhawale, D. U., Hajare, A. R. and Dhobe, S. G., 2008, Effect of plant growth regulators on size, yield and quality of acid lime. $J$. Soils \& Crops, 18: 117-120.

Singh, B., Yadav, A. L. and Meena, A. K., 2017, A study on foliar feeding of $\mathrm{GA}_{3}$ and NAA on vegetative growth and yield of phalsa (Grewia subinaequalis D.C.). Int. J. Curr. Microbiol. Appl. Sci., 6: 768-775.

Somavanshi, A. V., Haldankar, P. M. and Dandekar, V. S., 2012, Effect of post flowering foliar sprays of nutrient on fruit growth of kokum (Garcinia indica Choisy). J. Spices and Aromatic Crops, 21: 48-52.

Tahir, F. M., Ibrahim, M. and Kamran, H., 2002, Effect of growth retardants on vegetative and reproductive growth behaviour of mango. J. Biol. Sci., 2: 727-728.

Thejeswini, R. and Teggi, M. Y., 2015, Acid lime cultivation in Vijaypur district: growth prospects and problems, Karnataka J. Agric. Sci., 28: 633-635.

Thirugnanavel, A., Amutha, R., Baby Rani, W., Indira, K., Mareeswari, P., Muthulaksmi, S. and Parthiban, S., 2007, Studies on regulation of flowering in acid lime (Citrus aurantifolia Swingle). Res. J. Agri. Biol. Sci., 3: 239-241.

Yeshitela, T., Robbertse, P. J., Stassen, P. J. C., 2004, Potassium nitrate and urea sprays affected flowering and yields of mango in Ethiopia. South African J. Pl. \& Soil, 22: 154-172.

\section{How to cite this article:}

Obadiya Rai, S.N. Patil, D.R. Patil, Venkatshalu, Mallikarjun Awati and Kiran, K.C. 2018. Effect of Plant Growth Regulators and Chemical on Vegetative and Reproductive Parameters during Hasta Bahar in Acid Lime (Citrus aurantifolia Swingle). Int.J.Curr.Microbiol.App.Sci. 7(09): 2640-2650. doi: https://doi.org/10.20546/ijcmas.2018.709.330 